https://helda.helsinki.fi

\title{
Language matters? Antecedents and political consequences of support for bilingualism in Canada and Finland
}

\section{Medeiros, Mike}

2020

Medeiros , M , von Schoultz , $\AA$ \& Wass , H 2020 , ' Language matters? Antecedents and political consequences of support for bilingualism in Canada and Finland ', Comparative European Politics , vol. 18 , pp. 532-559 . https://doi.org/10.1057/s41295-019-00198-x

http://hdl.handle.net/10138/326728

https://doi.org/10.1057/s41295-019-00198-x

acceptedVersion

Downloaded from Helda, University of Helsinki institutional repository.

This is an electronic reprint of the original article.

This reprint may differ from the original in pagination and typographic detail.

Please cite the original version. 


\title{
Language Matters? Antecedents and Political Consequences of Support for Bilingualism in Canada and Finland
}

\author{
Accepted for publication in Comparative European Politics \\ https://doi.org/10.1057/s41295-019-00198-X
}

[Published version may differ slightly]

Mike Medeiros, Åsa von Schoultz \& Hanna Wass

\begin{abstract}
Language policies are important sociopolitical features of multilingual countries. Not only do they regulate relations with governmental authorities, but they can also impact intergroup relations. Yet, empirical research has tended to ignore language policies. Very little is known in relation to the factors that lead individuals to support or oppose such policies. Furthermore, to the best of our knowledge, there is relatively little knowledge regarding the influence of attitudes towards language policies on subsequent political phenomena. The present article seeks to address these gaps by exploring bilingualism in Canada and Finland. Specifically, using survey data from both countries' national election studies, the article, firstly, examines factors that can account for support towards bilingualism and, secondly, it investigates the relationship of these attitudes with vote choice. The results reveal two main findings. Firstly, support for bilingualism seems to be associated with context specific factors; a general pattern of determinants is not supported by the results. Secondly, attitudes towards bilingualism are found to have a significant association on vote choice in both Canada and Finland.
\end{abstract}

Keywords: Bilingualism, Minorities, Voting, Canada, Finland 


\section{Introduction}

Language policies in a multilingual country can be an emotionally charged topic, which can have important consequences for the sociopolitical stability of such countries (Lecours 2012; Safran and Liu 2012). Language policies are thus of primary importance in multilingual societies as they regulate the relationships between linguistic groups as well as these groups' relations with the state.

Language policies in Canada had been for decades a source of important political and social tensions. Language politics escalated in the 1960s in Canada when the Francophone minority demanded greater rights for their language, provoking - in turn - a backlash from some in the Anglophone majority who saw bilingualism as disadvantaging them (McRoberts 1997; Ullman 1986). While linguistic tensions arguably played a prominent role in Canada for several decades, language politics are no longer as pronounced as they once were (Medeiros 2019). This situation is arguably different than the one that currently exists in Finland. While bilingualism in Finland always had its critics, they for long remained at the margins of the political landscape with the three dominating political parties officially or actively supporting two national languages (Saukkonen 2012; Meinander 2016). Yet, the situation has gradually changed since the 1990s with the status of Swedish in Finland becoming more politicized (Saukkonen 2013; Ihalainen \& Saarinen 2015).

While Canada and Finland seem to be on different paths of the bilingualism debate, language politics has nevertheless impacted the history of both countries. However, we do not know if positions towards bilingualism are actually associated with the politics of these two countries due to a lack of empirical research on the subject. This gap in knowledge corresponds to an observation made by Phillipson (1999), in which he remarked that although language policies play such a crucial sociopolitical role in multilingual countries the subject has not received much attention from political science. Although the situation has improved in recent decades (see, for example, Palozzi 2006; Robinson et al. 2006.), there is still relatively little knowledge related to determinants of attitudes towards language policies.

Still, while the scholarship has highlighted that social cleavages in countries with linguistic minorities can lead to electoral politics being divided along these social lines (Bengtsson 2011), a wider take on how attitudes towards bilingualism are associated with electoral behaviour, moving beyond the specific expectations of language minorities supporting parties representing their 
interests, is however still lacking. This can be considered as an important topic to explore at a time when populist parties, often with a nationalist and chauvinist (and hence antagonistic towards minorities) agenda, are attracting support in many countries.

The present article takes a two-step empirical approach in its exploration of support for bilingualism. It firstly aims at outlining the political factors driving support for or against bilingualism. It contributes to our knowledge of attitudes towards pluralist language policies. The article thereafter examines how support or opposition towards bilingualism influences vote choice in multilingual contexts. We do so by exploring two countries in which language politics are at different saliency levels: Canada and Finland. While both are de jure bilingual countries, their differences in terms of linguistic demographics, language group status, and the saliency of language politics provide a comparative framework that allows to test the generalizability of the determinants on the outcomes. We specifically utilize survey data from national election studies performed in conjunction with the 2015 Finnish and Canadian parliamentary elections.

The results reveal two main findings. Firstly, support for bilingualism seems to be correlated to context specific factors; a general pattern of determinants is not supported by the results. Secondly, attitudes towards bilingualism are found to have a significant relationship with vote choice in both Canada and Finland. Therefore, language policies, specifically attitudes towards them, impact electoral politics in multilingual countries.

\section{Attitudes towards Language Policies: Antecedents and Political Consequences}

Phillipson (1999) remarked that political scientists needed to accord more attention to language policies. In the nearly two decades since this call for political science to explore language policies, no clear sociopolitical picture of the issue has emerged.

The few studies that have empirically examined support for bilingualism have highlighted sociodemographic factors. For instance, Azaiza and colleagues' study (2011) on Jews and Arabs in Israel finds that age and education impact support for bilingualism. In the United States, Robinson and colleagues (2016) showed that support for English as the only official language was higher among older, more conservative and Republican respondents and lower among the collegeeducated, women, non-whites and residents of urban areas and on the coasts. However, a study by Çelebi and colleagues (2016), regarding support for Kurdish language rights in Turkey, takes the analytical framework a step further and highlights the importance of identity in supporting (or not) 
bilingualism. Specifically, stronger identification with the Turkish identity was associated with less support for minority language rights in both ethnic Turks and Kurds. Palozzi (2006) also highlights the importance of identity in the development of pluralist, or assimilationist, linguistic policy preferences in the United States.

Research has generally shown that members of linguistic minorities are unsurprisingly more supportive of bilingualism policies than majority group members ( McRae 1983; Sniderman et al. 1989). For linguistic minorities, this discrepancy can be understood by the socioeconomic benefits as well as the identity-based security that bilingualism provides (Harel-Shalev 2006; Saideman and Ayres 2000). Language policies perceived as unacceptable by minorities can result in a revolt against the polity (Lecours 2012). In the case of the majority group, pluralism can present a threat to the country's identity, as formulated by the majority, and even to its territorial integrity, explaining the potential preference for assimilationist policies by majorities (McRae 1997; Hehman et al. 2012). Specifically regarding language, bilingualism can be perceived as an advantage to the minority and, therefore, a disadvantage to the majority group (Ullman 1986). This is especially true from an economic perspective as perceived economic threat leads majority group members to espouse more negative attitudes towards minorities (Wilkes et al. 2008; Citrin et al. 1997). Yet, this economic threat argument as it relates to bilingualism has remained, to our knowledge, to be empirically explored.

Therefore, seeing that there have been relatively few empirical studies on support for pluralist linguistic policies, the need for further research clearly exists. In general, we need to better understand which factors lead to greater (or lesser) support for bilingualism as well as explore whether these correlates are universal or more context specific.

In terms of the connection between political behaviour and attitudes towards language policies, there is, as far as we can tell, a dearth of research on the matter.

Although demographic variables related to language, such as mother tongue, are common features in studies exploring political behaviour in multilingual states, linguistic attitudes have not garnered much attention in such studies. We could only find a few studies that specifically explored the influence of linguistic attitudes on political outcomes. All of them focus on Quebec and show that perceptions of linguistic threat positively impact support for the secession (for example, see Nadeau and Fleury 1995; Medeiros 2017). 
This scholarly situation is ever the more peculiar as the literature emphasizes competition between political parties - by using rhetoric on language to appeal to particular groups (majority or minority) - as leading to the politicization and saliency of issues related to linguistic policies (Liu and Ricks 2012; Lublin 2013).

We, consequently, are also left to wonder: How does support for bilingualism impact vote choice in multilingual countries?

To explore the questions that we put forward, we examine two cases in which bilingualism has persistently been an important political issue but in which the politicization of linguistic policies is presently at different levels: Canada and Finland.

\section{Similar Language Policies, Different (Current) Language Politics}

Canada and Finland are Western, liberal democracies with important linguistic minorities: Francophones in the former and Swedophones in the latter. Both countries provide an official national status for their minority language, making them de jure bilingual states. However, both countries also have marked differences in relation to their linguistic minorities. Firstly, the size of the respective minorities is quite different. In Canada, mother tongue Francophones account for just under a quarter of the country's population; whereas in Finland, Swedophones represent just above five per cent of the population. Secondly, Francophones in Canada were traditionally an economically disadvantaged group compared to the Anglophone majority. The situation for Swedophones in Finland has been different, as they were historically a high-power group. Though they de facto constitute a relatively small minority group (5.2\% in 2018), Swedish is de jure constitutionally equal to Finnish. Furthermore, Swedophones can still be considered as a relatively strong minority with economic influence (Bengtsson 2011). Thirdly, the issue of language policies currently holds a divergent place in the political debates of each country.

Although present throughout Canadian history, tensions between Francophones and Anglophones took a sharp rise in the 1960s. Though Francophones formed a third of the population at Confederation (foundation of modern Canada) in 1867, French was far from being in practice at par with English. There was an awakening in the 1960s of Francophones in Quebec, where the group accounts for the large share of the population. They would no longer accept the underrepresentation of French in the Canadian federal infrastructure (McRoberts 1997). 
The growing discontent among Francophones and the rise of Quebec secessionism prompted the federal government to act. Their response was to truly promote bilingualism; first with the Official Languages Act of 1969 and thereafter, in 1982, enshrining minority linguistic rights in the Constitution (Esman 1982). Bilingualism would be positively regarded by some Anglophones because it distinctly defined modern Canada, and allowed them to distinguish themselves from Americans (Elkins 1989). However, the attempts to enhance the place of French in Canada also led to a backlash by many in the Anglophone majority (Esman 1982; Ullman 1986).

The period from Quebec's quiet revolution (1960s) until the second Quebec Referendum on Secession (1995) can be summarized as a continuous political debate over the place of Quebec and the French language in Canada. The language issue was evidently politicized by Quebec nationalists and groups representing Francophones outside Quebec. But the issue was also politicized on the Anglophone side. The linguistic discontent felt by many Anglophones was particularly channelled by the populist Reform Party (Laycock 2005).

However, since the turn of the millennium, the salience of language on Canadian politics has arguably whined (Medeiros 2019). This decline not only coincides with the waning of the Quebec secessionist movement (see Vallée-Dubois et al. 2017), but also with the end of the populist Reform Party. Seeing that a divided right made it easy for the centre-left Liberal Party of Canada (LPC) to stay in power, the successor of the Reform Party, the Canadian Alliance, merged with the Progressive Conservatives to unite the right and form the Conservative Party of Canada (CPC). Given that the new party needed to position itself closer to the ideological centre and to attract voters in Quebec, if it hoped to one day govern, its hostility towards bilingualism was quashed. Important efforts were made, especially by Prime Minister Stephen Harper - who came from the Reform Party - to show the importance of Canada's two official languages. This is in line with the theoretical reasoning that states that coalitional constraints determine language policies and that majority group elites can become accommodating of minority languages when there are electoral needs (Liu and Ricks 2012). However, the Conservatives in government did not always appoint bilingual individuals to important positions in the federal infrastructure (e.g., Supreme Court judges and the auditor general), to the ire of opposition parties and the country's Francophones.

In Finland, while Swedish has never been the language of the demographic majority, it has throughout history held a strong social position. During the long period in which the territory was 
an integral part of the Kingdom of Sweden (until 1809), Swedish was the language used by the ruling classes and for public administration. This was especially pronounced in the former capital of Turku/Åbo. Even today, it holds a prominent social role along the southwest coastline of Finland, an area traditionally referred to as Svenskfinland (Swedish Finland). A notion of Swedophones as belonging to a higher or upper class still persists; despite the fact that the predominant share of all socioeconomic groups is comprised of Finnophones (McRae 1997; Meinander 2016).

The Swedophone community has gone through a substantial demographic change. In the early seventeenth century, Swedish-speakers corresponded to about a fifth of the population. Since then, their share of the population has steadily decreased. In 2013, they accounted for just over five per cent of the Finnish population (Finnäs 2004).

In terms of the place of Swedish in Finnish society, it was not until the end of the nineteenth century, as part of the Russian empire, that the language debate became politicized; resulting in the formation of party alliances based on language interests (Sundberg 2016). At that time, the use of Finnish in official public domains had increased and the Finnish nationalist movement had grown strong (Alapuro \& Stenius 1987). The final breakthrough for Finnish as the primary public language came with the establishment of the unicameral Parliament and the introduction of universal suffrage in 1906. Before the first democratic election in 1907, several official parties were formed, among them the Swedish People's Party (RKP), which has since then gathered a substantial part of the Swedophone vote (Bengtsson et al. 2005; Meinander 2016). The national movements in the late nineteenth century did however also unite Finnophones and Swedophones and, when Finland gained its independence in 1917, both languages were rewarded with the status of official national languages. Since then, the status of the Swedish language has been officially recognized but has slowly weakened in the public domain (Meinander 2015).

Language disputes between Finnophones and Swedophones have been present since the 1860 s, but its intensity has varied and overall the situation can be described as peaceful. A dominating political majority has been, and still is, in favour of the linguistic status quo, with two national languages and the (formal) equal right to public services in both languages from the state officials and at the municipality level (in bilingual municipalities). Nevertheless, linguistic tensions around education and government services had simmered below the political consensus, 
and in the 1990s they started coming into the political forefront (Meinander 2015; Broermann 2007).

The language issue has grown politically relevant in the past two decades, driven by the issue of compulsory education in the second national language (i.e., Swedish for Finnophones and Finnish for Swedophones); the debate has even seen the negatively connoted term "mandatory Swedish" (pakkoruotsi) widely used (Meinander 2016). Abolishing compulsory education in the second national language has, for example, been raised by youth organisation of the two main parties National Coalition (KOK) and the Center Party (KESK) (Ihalainen \& Saarinen 2015). The political actor, most actively contributing to politicising the language issue, however, is the Finns Party (PS). While PS' major electoral breakthrough came in the 2011 parliamentary election, it has managed to influence political debates since the turn of the millennium and has contributed to a clear deviation from the previously dominating political consensus regarding bilingualism. It is also worth noting that the debate regarding language education has not been limited to the political classes, as over 60,000 Finnish citizens supported in 2014 a citizens' initiative calling for the abolition of the mandatory second-language Swedish curriculum. In terms of parties, the PS and the RKP's clear stances on language policy have made them emerge as clear opponents in the language policy debate (von Schoultz, forthcoming).

While Canada and Finland are bilingual countries in which language policies have engendered important political debates, the language politics are presently at different levels of political saliency and politicization in the two countries. Both cases therefore allow us to ascertain the wider application of determinants of attitudes towards bilingualism and the latter's influence on voting.

\section{Data and Results}

In order to explore the questions we put forward, we used survey data from the national elections held in 2015 in both Canada and Finland, respectively from the 2015 Canadian Election Study (CES) (Fournier et al. 2015) and the 2015 Finnish National Election Study (FNES) (Grönlund and Kestilä-Kekkonen 2016). Both surveys were conducted in conjunction with their respective parliamentary elections, held in October in Canada and in April in Finland. ${ }^{1}$

To aid with interpretability, all scales were made to run on a negative to positive range, or a progressive to conservative one. 'Don't know', 'Refuse to answer' or 'Left Blank' answer 
choices were coded as missing. All continuous variables were converted into a 0 to 1 scale. All analyses were performed with weighted data. More details on the survey questions that were used are subsequently presented or can be found in the Appendix.

To our knowledge, these two surveys are among the very few publicly available survey datasets that include questions on attitudes towards language policies. Nevertheless, the differences between Canada and Finland regarding linguistic demographics, language group status, and, especially, the saliency of language politics allow for a comparative framework to test the generalizability of the predictors' influence on the dependent variables.

The LPC led by Justin Trudeau won enough seats to form a majority government. This result also meant the end to an era, nearly ten years, of Stephen Harper led Conservative governments. The issue of language was not ignored during the campaign. The two main opposition parties - the LPC and the New Democratic Party of Canada (NDP) - promised to better protect the use of French in the public sector and to increase public spending on Francophone cultural programs. These policy proposals differed from the Conservatives weak promotion of bilingualism while in government. Nevertheless, language was not a main issue during the campaign. Bilingualism wasn't even very salient in Francophone Quebec, where it took a back seat to the debate over the reasonable accommodation of immigrants and an overall desire for change (Bélanger and Nadeau 2016).

In Finland, pre-campaign polls where strongly in favour of the main opposition party, KESK, who also, despite a drop in popularity during the campaign, managed to win the most seats and form a new government with the KOK and the PS. While economic issues dominated the election campaign overall, social issues - immigration and minority rights were also very prominent. This rhetoric was strongly influenced by the PS, who claimed that the country's bilingualism was too expensive and that they intended to break the longstanding tradition of including the RKP in the government (a tradition dating back to 1979); this was a goal that was ultimately achieved, as the RKP - the main political representatives of the Swedophone minority - was pushed out of government and onto the opposition benches (Sundberg 2016).

Support for bilingualism serves as a dependent variable in the first series of analyses and an independent one in the final analyses. For the Canadian data, there was only one question measuring respondents' attitudes towards bilingualism. ${ }^{2}$ This variable was operationalized through a question with a four-point continuous measure asking agreement on whether "We have gone too 
far in pushing bilingualism in Canada". The Finnish data provided three measures of attitudes towards bilingualism: two questions on a 11-point continuous measure asking respondents to rate Finland having "two strong national languages" and Swedophones having a special status, as well as a question on a four-point scale on whether Swedish in school should be voluntary. Principal component analysis showed that the three variables were part of a single factor and reliability testing demonstrated a Cronbach's $\alpha$ score of 0.75 .

We firstly examine the mean support for bilingualism along mother tongue. The respondents' mother tongue was trichotomized into Anglophones/Finnophones, Francophones/Swedophones and Allophones categories. ${ }^{3}$ The results, displayed in Figure 1, show a very similar pattern for both countries. The linguistic majority groups display a negative (though barely) mean attitude towards bilingualism (Anglophones: 0.49 and Finnophones: 0.46) and the linguistic minority groups are quite supportive of bilingualism (Francophones: 0.74 and Swedophones: 0.82). As for Allophones, they fall in between national linguistic majorities and minorities while still having a mean positive attitude towards bilingualism (Canada: 0.55 and Finland: 0.58). The difference between the linguistic minorities compared to the linguistic majorities and Allophones are significant (at $\mathrm{p}<0.01$ ) in both countries, while the difference between the linguistic majorities and Allophones are not statistically different in the two countries. The similarity between both cases is striking and clearly demonstrates that the difference in political salience (politicization) of language between Canada and Finland is not directly related to a difference in support for bilingualism.

\section{- Insert Figure 1 here -}

In order to get a more precise idea of the determinants of support for bilingualism, OLS regressions were performed. Besides mother tongue, we also include in the analyses classic sociodemographic controls: gender, age and education. In both cases, the age of the respondents was divided into 11 ranked groups in order to form a 11-point continuous variable. As for education, we used a question that ascertains the respondents' highest completed level of education. In Canada, this variable is an 11-point continuous scale, whereas in Finland it is on a 9-point continuous scale. We also explore the potential of two attitudinal variables. Firstly, seeing as the review of the scholarship highlighted the importance of economic threat on attitudes towards 
minorities, we test for the possible association of perceived economic threat with support for bilingualism. Egocentric economic evaluation was ascertained in both countries from a question gauging, on a 4-point scale, the likelihood of a decrease in household income in the upcoming year. Secondly, we also explore the influence of religiosity. The decision to include this variable was taken because of research that has shown that the salience of religion in individuals decreases prejudice against minorities (Scheepers et al. 2002). In both countries, this variable is measured on a four-point scale. However, in Canada respondents are asked about the importance of religion in their lives whereas Finnish respondents were asked how religious they were. Finally, we also adjust for geographical clustering through the regions of the respondents. For Finland, we use the maakunta ${ }^{4}$; and for Canada, we use the provinces.

The results, displayed in Figure 2, show that support for bilingualism has different correlates in Canada and Finland. In both countries, the majority mother tongue group, Anglophones in Canada and Finnophones in Finland, have statistically lower support for bilingualism compared to the linguistic minority groups while Allophones do not show a significant difference in their level support for bilingualism compared to the linguistic minority.

As for the other independent variables, they show different correlations with support for bilingualism in both countries. The economic evaluation was interacted with the mother tongue of the respondents to better isolate the influence of egocentric economic threat. The results show that economic threat does not have a statistical influence on supporting bilingualism in Canada. But in Finland, the more positive Finnophones were about their economic perspectives the more supportive they were of bilingualism. This result points to economic threat being a reason why bilingualism is less supported by Finnophones in Finland.

Religiosity and gender also have a statistical impact on supporting bilingualism in Finland. The more religious Finnophones are the more supportive they are of bilingualism. As for gender, Finnish women are significantly more supportive of bilingualism than Finnish men. However, these two variables do not attain a level of significance in Canada. Education is shown to have a significant and strong positive influence on supporting bilingualism in Canada. Yet, education does not have a statistical influence in Finland. Another variable also shows a significant impact on attitudes towards bilingualism in both cases. While age attains statistical significance in both countries, its effect is opposite. Older Canadians are less supportive of bilingualism, whereas older Finns are more supportive of it. In terms of regional distinction (results in Table $2 \mathrm{~A}$ in the 
Appendix), in Canada only two provinces show a statistical difference with Quebec: New Brunswick and Alberta. As Francophone Quebec is the main 'beneficiary' of bilingualism, it would have been sensible to expect a greater regional difference. However, this is not the case as very Anglophones provinces such as Newfoundland and Saskatchewan do not show a statistical difference with Quebec. ${ }^{5}$ As for Finland, the results point to a greater regional influence as seven regions show a statistical and relatively large negative influence on support for bilingualism compared to Uusimaa (where there is a relatively large Swedophone population).

While the findings demonstrate that the majority linguistic group is significantly less supportive of bilingualism than the minority linguistic group, this is the only similar result for both cases. As many of the variables are only significant for one case, or significant in both countries but with contradictory effects, our results support that attitudes towards bilingualism in multilingual countries are determined in a context specific manner rather than lend credence to the existence of a general pattern of influence.

\section{- Insert Figure 2 here -}

We now turn to the potential impact of support for bilingualism on political behaviour. We do so by exploring its influence on vote choice.

For Canada, we retained the parties that were successful in electing members to the Canadian Parliament. We therefore examine the LPC, the CPC, the NDP, the Bloc québécois (BQ), and the Green Party of Canada (GPC). The same criterion was used for the mainland parties of Finland and the Eduskunta. ${ }^{6}$ We thus retained the Social Democratic Party (SDP), the KESK, the KOK, the RKP, the Christian Democrats (KD), the Green League (VIHR), the Left Alliance (VAS) and the PS.

To explore vote choice, we use the same variables as were included in the previous model but also adjust for the influence of ideology. Seeing as the literature has pointed to potential issues with using a single ideological dimension - a method that has long been called into question for exploring political outcomes (Gauvin et al. 2016; Albright 2010) — we grasp ideological positioning through two independent dimensions ascertaining social and economic positioning. For the Canadian data, we were able to form a scale for the social dimension by combining four questions gauging respondents' feelings on a 0 to 100 scale towards immigrants, racial minorities, 
Muslims and Aboriginals. Principal component analysis was performed and the results showed the variables loading onto a single factor, thus confirming that they relate to a common dimension. In terms of reliability, the Cronbach's $\alpha$ score for this scale is 0.88 . We were also able to form a scale for the social dimension in Finland by combining three questions ascertaining attitudes on a 0 to 10 scale towards multiculturalism, immigration, and sexual minorities. Principal component analysis was performed and the results showed the three items were part of a single factor, demonstrating that they relate to a single dimension. In terms of reliability, the Cronbach's $\alpha$ score for this scale is 0.76 .

As for economic ideology, in the Canadian case, we combined three questions: one on a four-point scale measuring attitudes towards unions, another on a three-point scale on corporate taxes, and a dichotomous variable on daycare funding. As for Finland, three questions on a 0 to 10 scale on the free market, the public sector and taxation were also combined. Principal component analysis was performed and the results showed the three items for both countries were part of a single factor. However, the Cronbach's $\alpha$ scores in both cases were below 0.7 . Thus, we opted not to create multi-item scales. Instead, we predicted - after using varimax rotation to improve principal-component score loadings - the factor scores with a regression scoring method. Principal components analysis was thereafter performed to test if the items for the social and economic ideological dimensions as well as those for the bilingualism variable loaded onto distinct factors. The results (not reported) demonstrate that the items in both countries loaded onto three distinct, orthogonal dimensions.

The findings of multinomial logistic regressions for Canada, displayed in Figure 3, demonstrate that support for bilingualism has an independent significant association with vote choice for the LPC and the CPC, positive for the former and negative for the latter. However, due to the separate party system created by the BQ, we analyse Quebec separately from the Rest of Canada (RoC), as it is the norm to do so (see, for example, Fournier et al. 2013). Demographically, the proportion of Francophones in Canada when excluding Quebec is comparable to that of Swedophones in Finland. The findings for the RoC, in Figure 5A in the Appendix, not only show that support for bilingualism on vote choice still holds for the LPC and the CPC, but it is also shown to be significantly and positively associated with voting for the NDP. Hence, bilingualism has a statistical relationship with voting for the three main parties in the RoC. As for Quebec, the results, displayed in Figure 6A in the Appendix, demonstrate that - contrary to the rest of Canada 
- attitudes towards bilingualism do not impact vote choice. ${ }^{7}$ This finding can be explained by the fact that majority Francophone Quebec has expectedly distinct attitudes towards bilingualism than the predominantly Anglophone RoC. Quebec is more supportive of bilingualism. This observation is supported by results of an independent sample t-test (not reported) that indicate a significant difference between respondents in Quebec and those in the RoC in terms of their attitudes towards bilingualism, with the former being strongly more supportive of bilingualism. A comparison of attitudes towards bilingualism by vote choice (not reported) demonstrates that this support in Quebec is strong regardless of party choice. Thus, there is little variance in Quebec in support for bilingualism across vote choice. Essentially, Quebecers are very supportive of it. Yet, results of means tests do show a significant difference with the NDP and BQ in comparison with the CPC. Even in Quebec, Conservatives are less supportive of bilingualism. ${ }^{8}$

\section{- Insert Figure 3 here -}

As for vote choice in Finland, support for bilingualism is also connected to voting behaviour, but in a lesser manner than in Canada. The results, displayed in Figure 4, show that bilingualism only has a significant and positive association with voting for the RKP. ${ }^{9}$ This is unsurprising as Swedophones are the main beneficiaries from Finland's bilingualism policies. As for the PS, the main antagonist against Finland's bilingualism, while support for bilingualism's negative association with voting for this party does not cross the $\mathrm{p}<0.05$ significance threshold, it does come close to doing so $(\mathrm{p}=0.069)$. Regarding the other parties, bilingualism does not show it coming close to having a statistical association with vote choice for them.

\section{- Insert Figure 4 here -}

The results of this series of analyses show that support for bilingualism has an independent connection to vote choice in Canada and Finland. Though the impact of bilingualism on vote choice is proportionally greater in Canada than in Finland, the findings clearly demonstrate that even when controlling for a series of attitudinal and demographic variables attitudes towards bilingualism help to structure voting in these two multilingual countries. 


\section{Conclusion}

Language policies can have important sociopolitical consequences in multilingual countries. Language rights can be perceived as restrictive and a disadvantage to the linguistic minority (Kymlicka 2001). But, the linguistic majority can also perceive to be disadvantaged by language policies (Ullman 1986; Laycock 2005). While the importance of language policies in multilingual states cannot be denied, scholarly research has not paid much attention towards understanding the factors that influence support or opposition towards plurilingual policies and whether these attitudes determine the wider political context of multilingual countries.

The present article seeks to address these gaps by exploring the antecedents and political consequences of support for bilingualism in Canada and Finland. We firstly examine which factors are associated with support or opposition towards bilingualism. The findings support the importance of mother tongue on attitudes towards bilingualism. Unsurprisingly, the linguistic majority is found to be much less supportive of bilingualism than the linguistic minority, while Allophones fall in between these two groups. Whereas the results for the linguistic majorities and minorities are to be expected, the one for Allophones is also in line with previous research. Specifically, Allophones see more of a job market advantage to bilingualism than majority group members (Shapiro and Stelcner 1981), yet they are more attracted to integrate into the majority group (Cardinal 2004). Allophones are thus more positive to bilingualism than the linguistic majority, but not as much as the linguistic minority.

Still, our research provides detail into support towards language policies beyond demographics. In particular, we test the impact of economic threat on attitudes towards bilingualism. In Finland, perceiving that one's economic situation will get worse helps to explain Finnophones' negative attitudes towards bilingualism. These results support the notion that bilingualism can constitute a threat to the majority group. Yet, economic threat has no statistical impact on support for bilingualism in Canada. Furthermore, besides the linguistic majority having significantly more negative attitudes towards bilingualism than the linguistic minority, all the other statistical determinants are different in both cases. This finding pushes us to conclude that support for language policies is determined by context specific factors rather than being a universal phenomenon. However, further research is obviously called for in other multilingual contexts to establish whether these attitudes are truly context specific or if international patterns can be isolated. 
Secondly, our study provides a novel insight into the impact of attitudes towards language policies on political outcomes. Specifically, the present research demonstrates that attitudes towards bilingualism are associated with vote choice. Our results show that support for bilingualism has an independent and significant relationship with voting. These findings support the importance of social cleavages and historical relations in electoral politics in multilingual countries. Specifically, attitudes towards bilingualism present a closer relation with vote choice in Canada than in Finland. Canada and Finland are multilingual countries in which language has historically defined politics. However, language politics are currently at different levels of saliency in both countries. While some Finnish political parties are actively debating the place of Swedish in their country, their Canadian counterparts have - for the moment - seemingly put the issue of language on the political back burner. Nevertheless, considering the differences in terms of linguistic demographics, language social status, and linguistic political saliency between Canada and Finland, these findings point to a possible universal pattern in the support of language policies and its political effects on voting.

Yet, while attitudes towards language policies might help structure electoral politics in multilingual countries, the reasons for this influence might be case specific. The fact that attitudes towards bilingualism are affecting in any noteworthy manner the vote choice for the two main protagonists in the language debate in Finland, the RKP and PS, seem to be mobilizing direct stakeholders in this 'active debate'. The debate on bilingualism might be rendering linguistic identities salient, as well as threatening them, and thus these identities might be having a more pronounced influence on electoral politics (Achen and Bartels 2016; Schwennicke 2017). Yet, in Canada the influence of these attitudes on vote choice seem to be passive, influenced by past social tensions, and underscores the enduring influence of social cleavages on electoral politics (Tilley 2015). Evidently, more research is called for to better understand the association of support or opposition towards bilingualism with vote choice.

While the present article contributes to the understanding of the antecedents and political consequences of support towards bilingualism, further research is necessary. Firstly, our data do not allow to ascertain the respondents' interpretation of bilingualism. This is an especially important factor for language minorities for which bilingualism might also mean a greater incursion of the dominant language. Thus, research is needed to understand whether linguistic minority members define bilingualism as positive or negative and how such a perception impacts 
other political attitudes and behaviours. Secondly, seeing the independent relationship with vote choice in an active and a passive linguistic debate context, electoral research in multilingual countries clearly needs to account for this factor. Considering that attitudes towards bilingualism can affect not only vote choice but, ultimately, the sociopolitical stability of multilingual countries, understanding these attitudes should be of a greater concern for researcher. We thus call for social science scholars, especially empirical political scientists, to heed Phillipson's call (1999) and finally start giving language policies the scholarly attention they deserve.

\section{Acknowledgments}

The authors acknowledge the funding provided by the Strategic Research Council of the Academy of Finland (grant no 312710) and the Academy of Finland (grant no 316239). We also thank this journal's anonymous referees for their advice and suggestions.

\section{Notes}

${ }^{1}$ The 2015 CES was administered to respondents during the election campaign and after the election, whereas the 2015 FNES is solely a post-election survey. The respondent samples for both surveys are based on quotas that seek to nationally represent gender, age and regional distributions.

${ }^{2}$ While another question in the CES asked respondents whether they agreed or not that "Federal government services should be provided in only one language, French in Quebec and English in the rest of Canada", we feel that this question does not capture attitudes towards bilingualism as it measures a specific conception of a bilingual Canada rather than support or opposition towards bilingualism. Nevertheless, all the analyses were also performed with a bilingualism variable that combined the two measures. The results (not reported) are essentially the same; the only difference is found in vote choice in the RoC (Figure 5A in the Appendix) as this alternate bilingualism measure is not shown to significantly and positively influence vote choice for the NDP but displays such an effect on voting for the GPC. 
3 The term Allophone refers to individuals whose mother tongue is neither the national majority language (English/Finnish) nor the national minority language (French/Swedish).

${ }^{4}$ The FNES excludes Åland from their survey.

${ }^{5}$ Seeing that the dependent variable for the Canadian case only has five choices of response, an ordinal logistic regression was also performed. The results (not reported) are essentially the same as those presented in Figure 2 and in Table $2 \mathrm{~A}$ in the Appendix.

We also performed the analyses for Canada with identification with Canada as a control, to test the findings found by Çelebi and colleagues (2016). The results (not reported) show that identity has a significant and relatively strong positive influence on support for bilingualism. However, when it is interacted with mother tongue, there is no significant support for a moderating effect of language groups, contrary to the results found by Çelebi and colleagues. The Finnish data did not include a measure of national identification.

${ }^{6}$ The Swedophone-majority islands of Åland have a completely different party system and only send one member to the Eduskunta.

${ }^{7}$ Due to an inability of the multinomial model to converge with the weighted data (seeing that we are using quite a small number of observations), these results are based on individual logistic regressions for each party.

${ }^{8}$ While we concentrate the description of the voting results on the influence of bilingualism, another relationship in the Canadian results needs further elaboration. Social ideology is shown to have a significant and positive influence on voting for the NDP. While this might seem unexpected for a left-of-center party to attract social conservatives, our results are similar to those found by Gauvin and colleagues (2016), who also use CES data and a similar multi-item variable to measure social ideology.

${ }^{9}$ Due to issues of singularity (caused by a small number of respondents who claimed to have voted for the RKP), and therefore the inability to estimate marginal effects for some of the variables, the model for the RKP is different than the one for the other parties. Mother tongue (Swedish vs. others) and regions (Uusimaa vs. other regions) had to be dichotomized in this model.

We also performed this analysis, along with the one to determine Support for bilingualism (Figure 2), with a regional variable that combined the three regions with the most Swedophones (Uusimaa and Varsinais-Suomi and Pohjanmaa vs. other regions). The results (not reported) are essentially the same, except for the influence of Support for bilingualism on voting for the PS no longer being close to crossing the $\mathrm{p}<0.05$ significance threshold. 


\section{References}

Achen, Christopher H., and Larry M. Bartels. 2016. Democracy for Realists: Why Elections Do Not Produce Responsive Government. Princeton: Princeton University Press.

Alapuro, Risto and Henrik Stenius. 1987. "Kansanliikkeet loivat kansakunnan" in Kansa Liikkeessä. Alapuro, R, Liikanen, I, Smeds, K \& Stenius, H. (eds.), Helsinki: Kirjayhtymä.

Albright, Jeremy J. 2010. "The Multidimensional Nature of Party Competition." Party Politics 16 (6):699-719.

Azaiza, Faisal, Rachel Hertz-Lazarowitz, Meyrav Shoham, Muhammad Amara, Aura MorSommerfeld, and Nohad 'Ali. 2011. "Attitudes Towards Bilingual Arab-Hebrew Education in Israel: A Comparative Study of Jewish and Arab Adults." Language, Culture and Curriculum 24 (2):179-93.

Bélanger, Éric, and Richard Nadeau. 2016. "The Bloc Québécois in a Rainbow-Coloured Quebec." In The Canadian Federal Election of 2015, ed. J. H. Pammett and C. Dornan. Toronto: Dundurn.

Bengtsson, Åsa. 2011. "Svenska Folkpartiet Som Förvaltare Av Det Politiska Och Sociala Kapitalet." In Det Finlandssvenska Sociala Kapitalet : Fakta Eller Fiktion. Helsinki: Svenska litteratursällskapet i Finland.

Bengtsson, Åsa, Kimmo Grönlund, and L. Karvonen. 2005. "Språk Och Parti." In Den Finlandssvenska Väljaren. Türku: Institutet för finlandssvensk samhällsforskning.

Broermann, Marianne. 2007. "Language Attitudes among Minority Youth in Finland and Germany." International Journal of the Sociology of Language 2007 (187-188):129-60.

Cardinal, Linda. 2004. "The Limits of Bilingualism in Canada." Nationalism and Ethnic Politics 10(1): 79-103.

Çelebi, Elif, Maykel Verkuyten, and Natasa Smyrnioti. 2016. "Support for Kurdish Language Rights in Turkey: The Roles of Ethnic Group, Group Identifications, Contact, and Intergroup Perceptions." Ethnic and Racial Studies 39 (6):1034-51.

Citrin, Jack, Donald P. Green, Christopher Muste, and Cara Wong. 1997. "Public Opinion toward Immigration Reform: The Role of Economic Motivations." Journal of Politics 59 (3):85881 .

Elkins, David J. 1989. "Facing Our Destiny: Rights and Canadian Distinctiveness." Canadian Journal of Political Science 22 (4):699-716.

Esman, Milton J. 1982. "The Politics of Official Bilingualism in Canada." Political Science Quarterly 97 (2):233-53.

Finnäs, F. 2004. "Finlandssvenskarna 2002. En Statistisk Rapport." Helsinki: Svenska Finlands Folkting. 
Fournier, Patrick, Fred Cutler, Stuart Soroka, and Dietlind Stolle. 2015. "The 2015 Canadian Election Study." Vancouver: University of British Columbia.

Fournier, Patrick, Fred Cutler, Stuart Soroka, Dietlind Stolle, and Éric Bélanger. 2013. "Riding the Orange Wave: Leadership, Values, Issues, and the 2011 Canadian Election." Canadian Journal of Political Science 46 (4):863-97.

Gauvin, Jean-Philippe, Chris Chhim, and Mike Medeiros. 2016. "Did They Mind the Gap? Voter/Party Ideological Proximity between the BQ, the NDP and Quebec Voters, 20062011." Canadian Journal of Political Science 49 (2):289-310.

Grönlund, Kimmo, and Elina Kestilä-Kekkonen. 2016. "Finnish National Election Study 2015." Tampere: Finnish Social Science Data Archive.

Harel-Shalev, Ayelet. 2006. "The Status of Minority Languages in Deeply Divided Societies: Urdu in India and Arabic in Israel - a Comparative Perspective." Israel Studies Forum 21 (2):28-57.

Hehman, Eric, Samuel L. Gaertner, John F. Dovidio, Eric W. Mania, Rita Guerra, David C. Wilson, and Brian M. Friel. 2012. "Group Status Drives Majority and Minority Integration Preferences." Psychological Science 23 (1):46-52.

Ihalainen, Pasi and Taina, Saarinen. 2015. "Constructing 'language' in language policy discourse : Finnish and Swedish legislative processes in the 2000s" in Language policies in Finland and Sweden. Interdisciplinary and multi-sited comparisons. Halonen, M; Ihalainen, P. \& Saarinen, T. (eds.), Bristol: Multilingual Matters.

Kymlicka, Will. 2001. Politics in the Vernacular: Nationalism, Multiculturalism and Citizenship. Oxford: Oxford University Press.

Laycock, David. 2005. "Populism and the New Right in English Canada." In Populism and the Mirror of Democracy, ed. F. Panizza. London: Verso.

Lecours, André. 2012. "Sub-State Nationalism in the Western World: Explaining Continued Appeal." Ethnopolitics 11 (3):268-86.

Liu, Amy H., and Jacob I. Ricks. 2012. "Coalitions and Language Politics: Policy Shifts in Southeast Asia." World Politics 64 (3):476-506.

Lublin, David. 2013. "The 2012 Latvia Language Referendum." Electoral Studies 2 (32):385-7.

McRae, Kenneth Douglas. 1983. Conflict and Compromise in Multilingual Societies: Swtizerland. Vol. 1. Waterloo, Ont.: Wilfrid Laurier University Press

- 1997. Conflict and Compromise in Multilingual Societies: Finland. Vol. 3. Waterloo, Ont.: Wilfrid Laurier University Press. 
McRoberts, Kenneth 1997. Misconceiving Canada: The Struggle for National Unity. Oxford: Oxford University Press.

Medeiros, Mike. 2019. "National Frenemies: Linguistic Intergroup Attitudes in Canada." Ethnic and Racial Studies 42(16):3-22.

_ 2017. "Refining the Influence of Language on National Attachment: Exploring Linguistic Threat Perceptions in Quebec." Nationalism and Ethnic Politics 23 (4):375-90.

Meinander, H. 2015. "Språkfrågan Sedan 1863." In Makten Att Kombinera. Utmaningar, Vägval Och Handlingskraft I Svenskfinland, ed. S. Sjöblom and S. Sandberg. Helsinki: Svenska kulturfonden.

Meinander, Henrik. 2016. Nationalstaten. Finlands svenskhet 1922-2015. Helsingfors: Svenska Litteratursällskapet i Finland.

Nadeau, Richard, and Christopher J. Fleury. 1995. "Gains Linguistiques Anticipés et Appui à la Souveraineté du Québec." Canadian Journal of Political Science 28 (1):35-50.

Palozzi, Vincent J. 2006. "Assessing Voter Attitude toward Language Policy Issues in the United States". Language Policy 5 (1), 15-39.

Phillipson, Robert. 1999. "Political Science." In Handbook of Language and Ethnic Identity, ed. J. A. Fishman. Oxford: Oxford University Press.

Robinson, John P., Rivers William P., and Brecht, Richard D. 2006. "Demographic and Sociopolitical Predictors of American Attitudes towards Foreign Language Policy." Language Policy 5 (4), 421-42.

Safran, William, and Amy H. Liu. 2012. "Nation-Building, Collective Identity, and Language Choices: Between Instrumental and Value Rationalities." Nationalism and Ethnic Politics 18 (3):269-92.

Saideman, Stephen M., and R. William Ayres. 2000. "Determining the Causes of Irredentism: Logit Analyses of Minorities at Risk Data from the 1980s and 1990s." Journal of Politics $62(4): 1126-44$.

Saukkonen, Pasi. 2012. "The Finnish Paradox: Language and Politics in Finland." Recode Working Paper Series (5):1-12.

Saukkonen, Pasi. 2013. Erilaisuuksien Suomi. Vähemmistö- ja kotouttamispolitiikan vaihtoehdot. Gaudeamus Helsinki University Press.

Scheepers, Peer, Merove Gijsberts, and Evelyn Hello. 2002. "Religiosity and Prejudice against Ethnic Minorities in Europe: Cross-National Tests on a Controversial Relationship." Review of Religious Research 43 (3):242-65. 
von Schoultz, Åsa. (forthcoming). "Åsiktsöverensstämmelse i språkfrågan - Representerar partierna väljarnas åsikter?" in Ur majoritetens perspektiv. Förklaringar till finskspråkiga finländares åsikter om svenskan $i$ Finland. Himmelroos, S. \& Strandberg, K (eds.). Helsingfors: Svenska Litteratursällskapet i Finland.

Schwennicke, Antje. 2017. "A Discussion of Christopher H. Achen and Larry M. Bartels' Democracy for Realists: Why Elections Do Not Produce Responsive Government." Perspectives on Politics 15 (1):148-51.

Shapiro, Daniel M., and Morton Stelcner. 1981. "Male-Female Earnings Differentials and the Role of language in Canada, Ontario, and Quebec, 1970." The Canadian Journal of Economics 14(2):341-348.

Sniderman, Paul M., Joseph F. Fletcher, Peter H. Russell, and Philip E. Tetlock. 1989. "Political Culture and the Problem of Double Standards: Mass and Elite Attitudes toward Language Rights in the Canadian Charter of Rights and Freedoms." Canadian Journal of Political Science 22 (2):259-84.

Sundberg, Jan. 2016. "Finland." In European Journal of Political Research: Political Data Yearbook

ed. A. Bågenholm, K. Deegan-Krause and L. Weeks: Blackwell.

Tilley, James. 2015. "'We Don't Do God'? Religion and Party Choice in Britain." British Journal of Political Science 45 (4):907-27.

Ullman, Stephen H. 1986. "The Political Attitudes of New Brunswick's Acadians and Anglophones: Old Wine in Old Bottles?" American Review of Canadian Studies 16 (2):161-80.

Vallée-Dubois, Florence, Ruth Dassonneville, and Jean-François Godbout. 2017. "About Time: Age, Period, and Cohort Effects on Support for Quebec Sovereignty." Nations and Nationalism.

Wilkes, Rima, Neil Guppy, and Lily Farris. 2008. "“No Thanks, We're Full”: Individual Characteristics, National Context, and Changing Attitudes toward Immigration1." International Migration Review 42 (2):302-29. 
Figure 1: Mean Support for Bilingualism per Mother Tongue

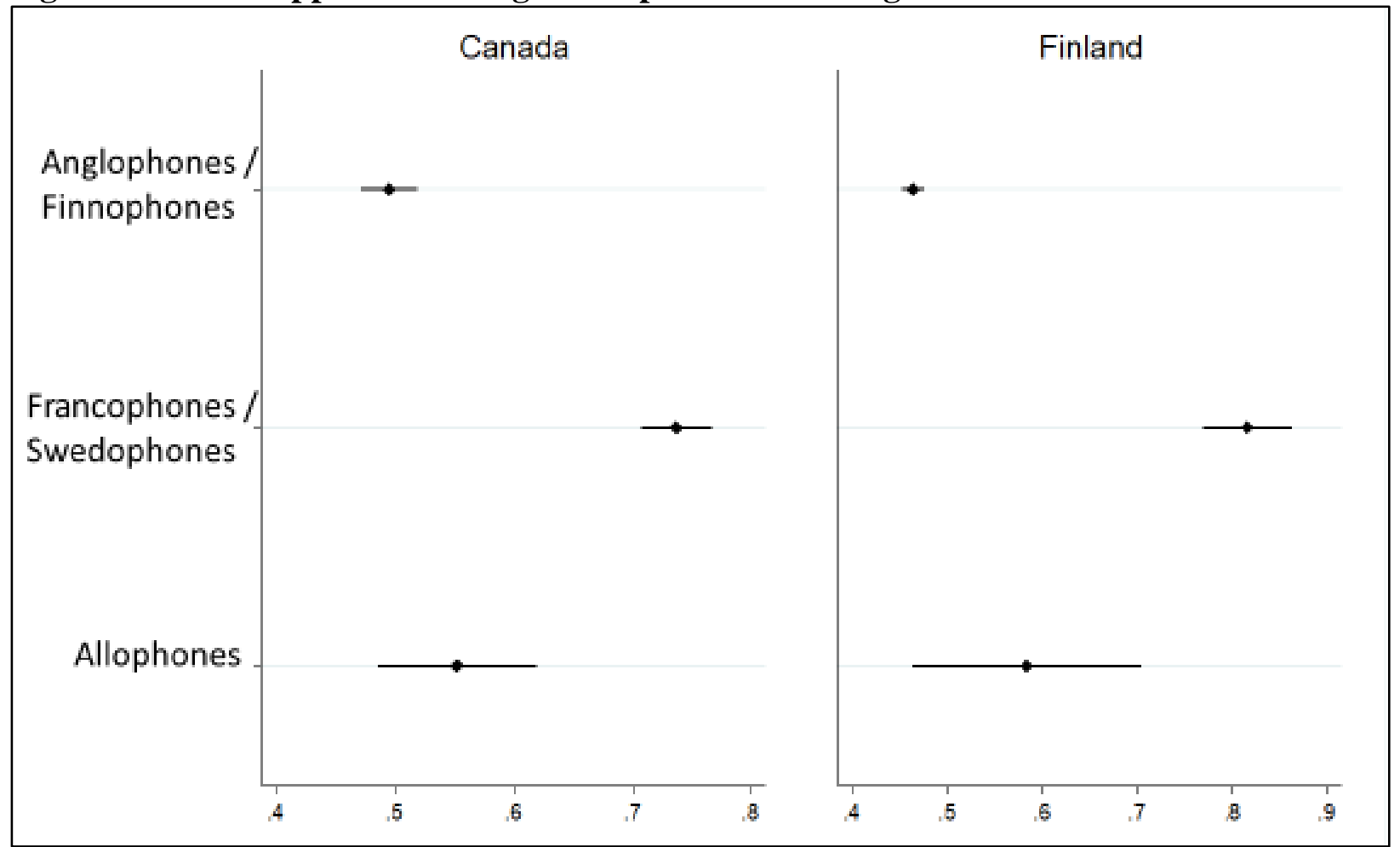

Markers report averages on a 0-1 scale and bars represent confidence intervals at $95 \%$. Numbers of observations are 1205 for Canada and 1587 for Finland. 
Figure 2: Determinants of Support for Bilingualism

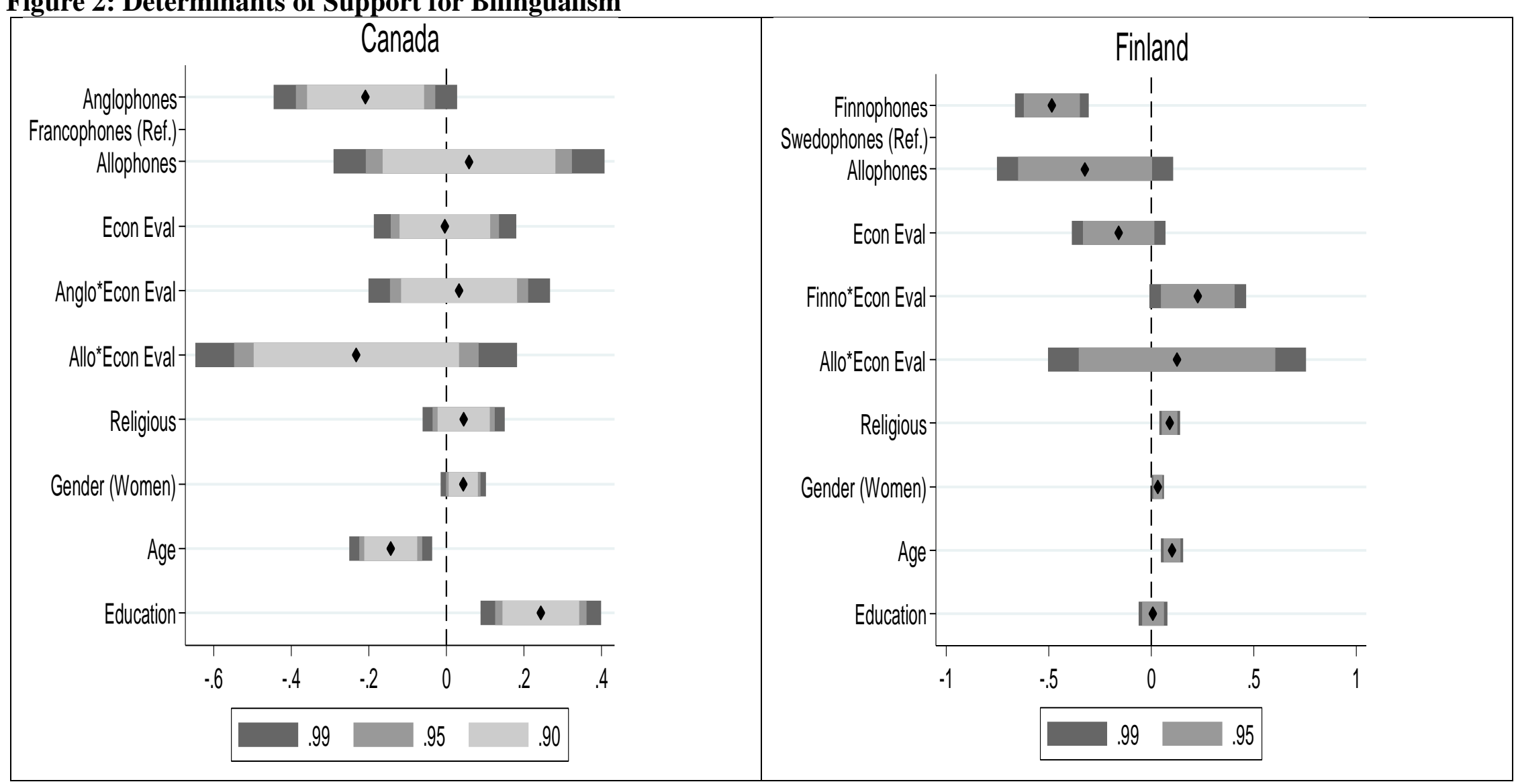

Markers represent OLS coefficients. Models also includes regions, see Table 2A in the Appendix. Numbers of observations are 820 for Canada and 1504 for

Finland. Seeing as the Canadian data has a relatively small number of observations, we use an extra level of significance for that case. 
Figure 3: Determinants of Vote Choice - Canada

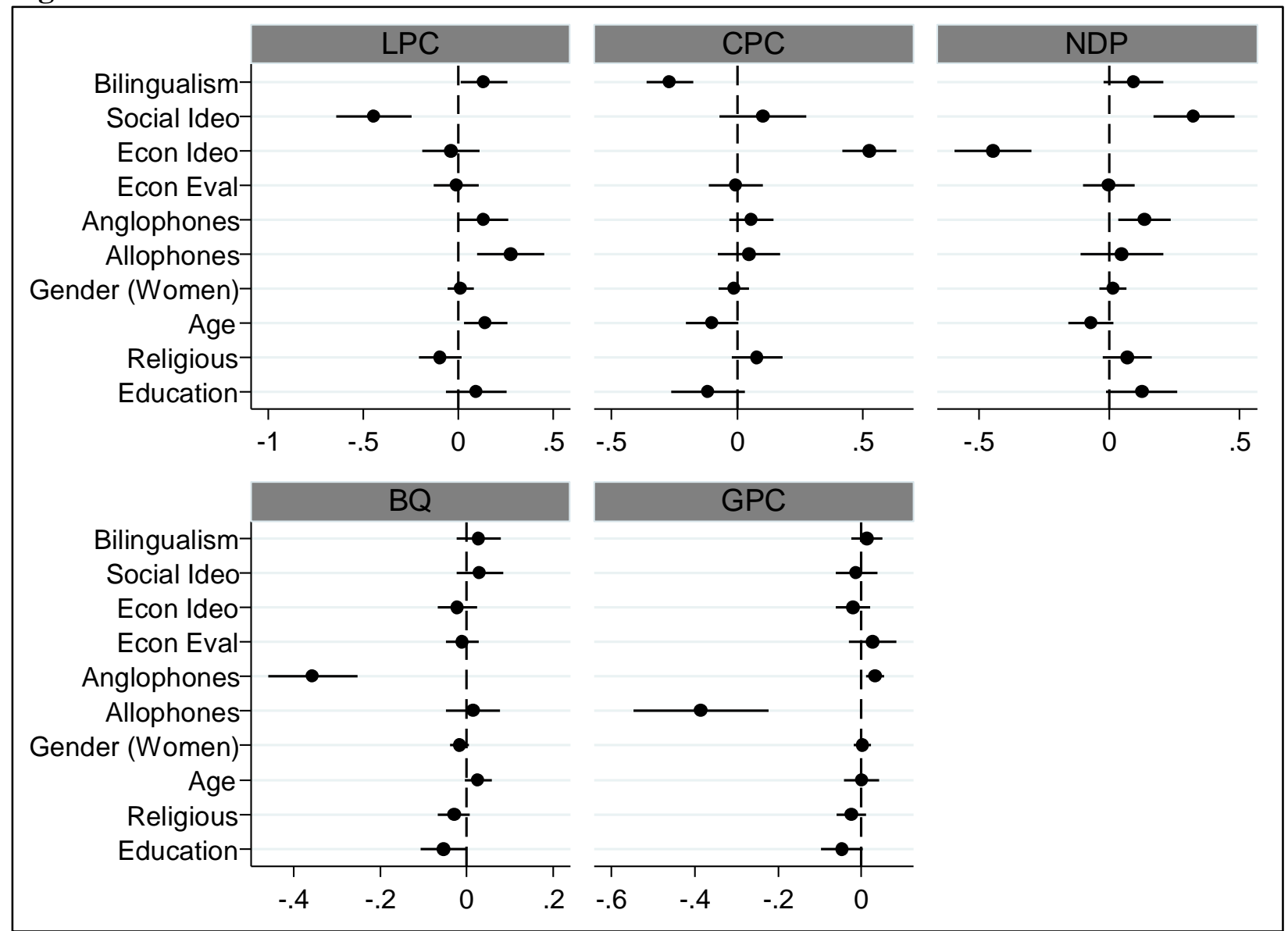

Markers represent average marginal effects (90\%) from a multinomial regression. The model also includes regions.

See Table $3 \mathrm{~A}$ in the Appendix for more information. 
Figure 4: Determinants of Vote Choice - Finland

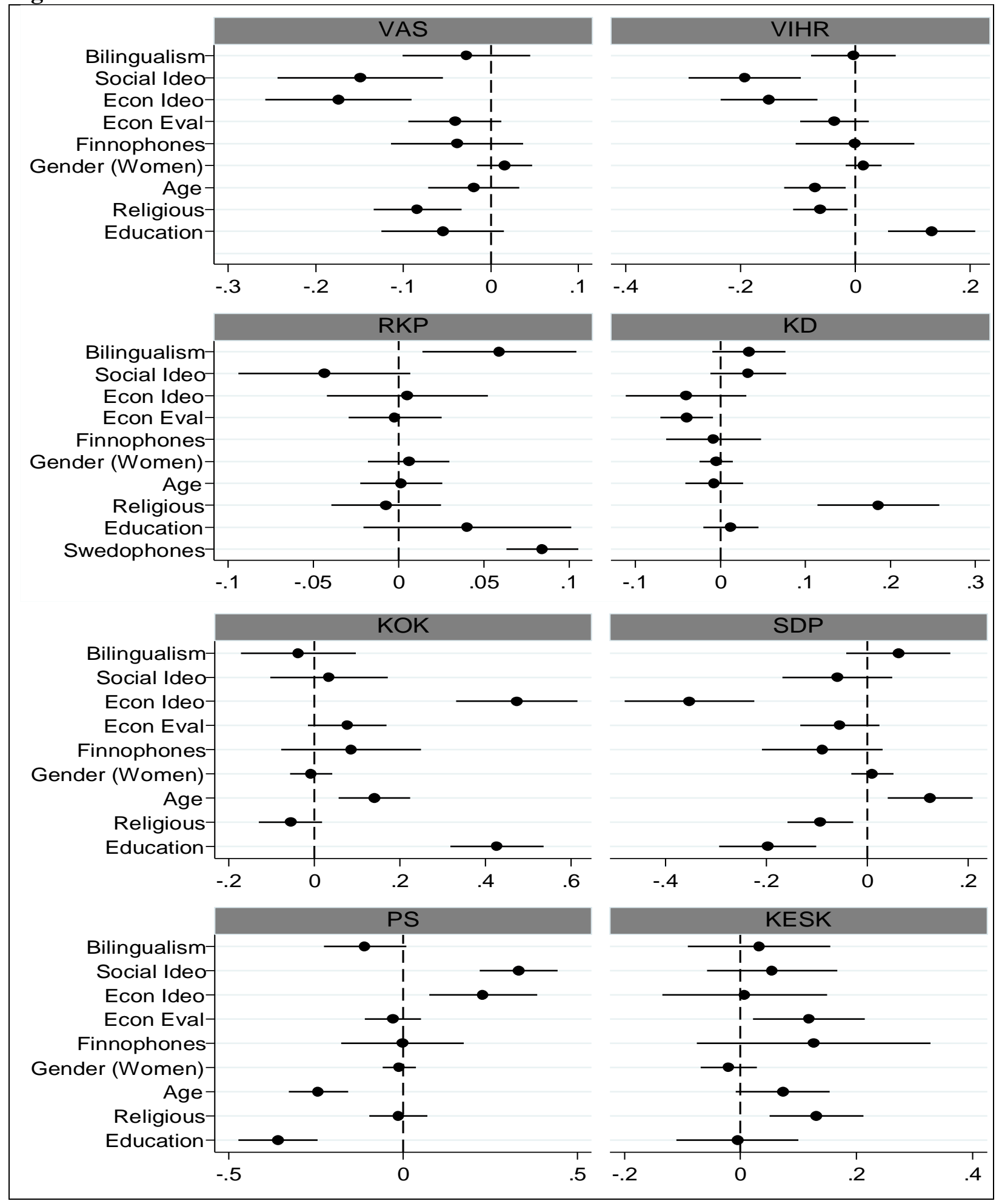

Markers represent average marginal effects (95\%) from multinomial regressions. The models also include regions.

See Table 4A in the Appendix for more information. 


\section{Appendix}

\section{Questions used}

\section{Bilingualism}

\section{Canada}

We have gone too far in pushing bilingualism in Canada.

\section{Finland}

Finland where the special status of Swedish-speaking Finns is acknowledged.

Finland that has two strong national languages: Finnish and Swedish.

Studying Swedish at school should be voluntary.

\section{$\underline{\text { Social Ideology }}$}

\section{Canada}

How do you feel about immigrants?

How do you feel about racial minorities?

How do you feel about Muslims?

How do you feel about Aboriginals?

\section{Finland}

Multicultural Finland where foreigners with different religions and lifestyles are tolerated.

Finland where the status of sexual minorities is reinforced.

Finland that has more immigration.

\section{Economic Ideology}

\section{Canada}

Should corporate taxes be increased, decreased, or kept about the same as now?

Please indicate how much confidence you have in the following institutions. Unions?

What should the government do: fund public daycare, or give the money directly to parents?

\section{Finland}

Finland that has more entrepreneurship and market economy.

Finland that has a smaller public sector. 
Finland that has a lower taxation level.

$\underline{\text { Economic Evaluation }}$

Canada

Re: household's main sources of income: First, how likely is it that this income will be lost in the next year? Is it very likely, somewhat likely, somewhat unlikely, or very unlikely?

Finland

How likely or unlikely do you think it is that your household's income could be severely reduced in the next 12 months?

\section{$\underline{\text { Religiosity }}$}

Canada

In your life, would you say religion is very important, somewhat important, not very important, or not important at all?

Finland

How religious would you say you are?

\section{$\underline{\text { Education }}$}

\section{Canada}

What is the highest level of education that you have completed?

\section{Finland}

What is the highest level of education or degree you have completed? 
Figure 5A: Determinants of Vote Choice - Rest of Canada

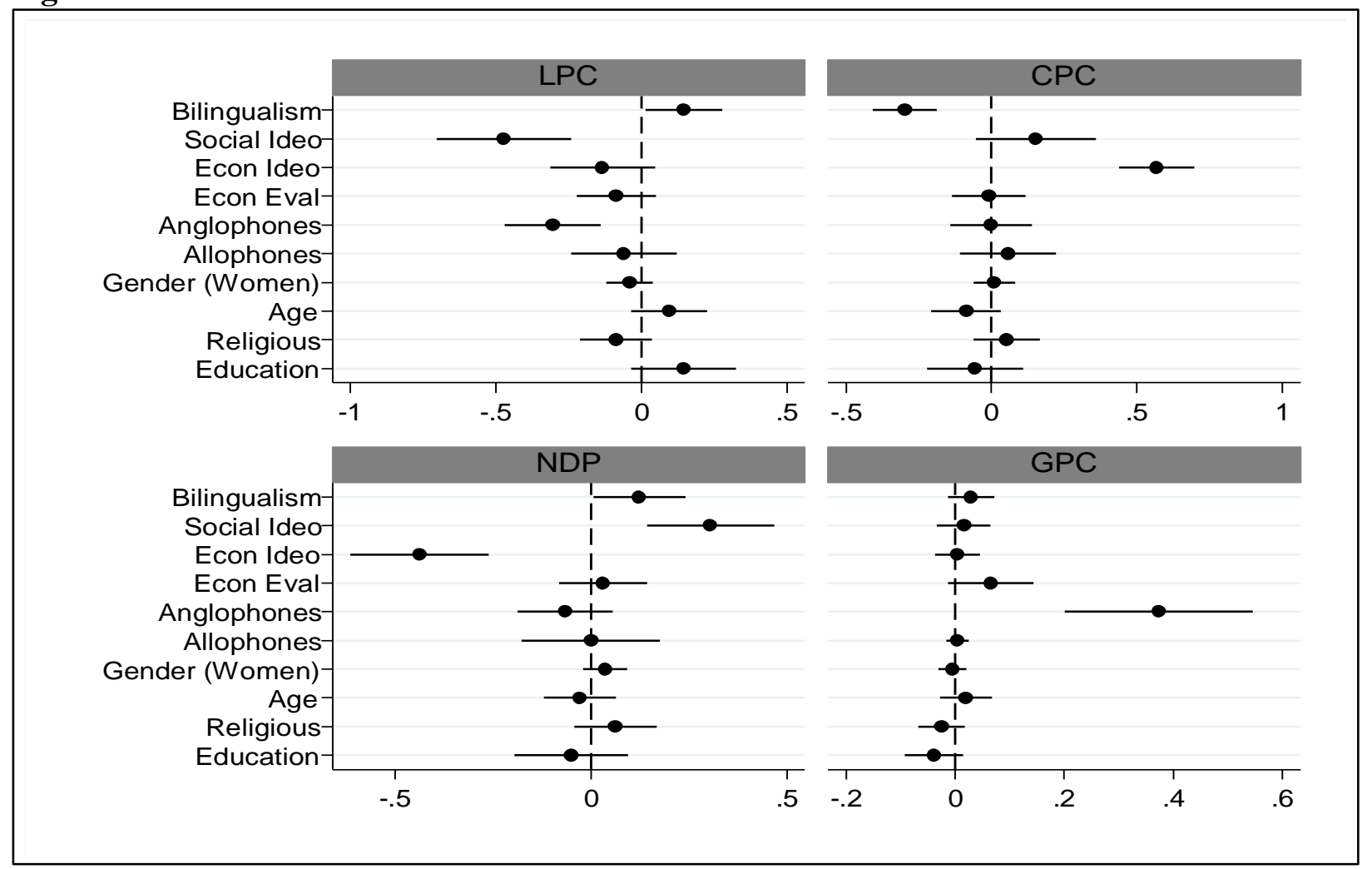

Markers represent average marginal effects (90\%) from a multinomial regression. The model also includes regions and includes 503 observations. 
Figure 6A: Determinants of Vote Choice - Quebec

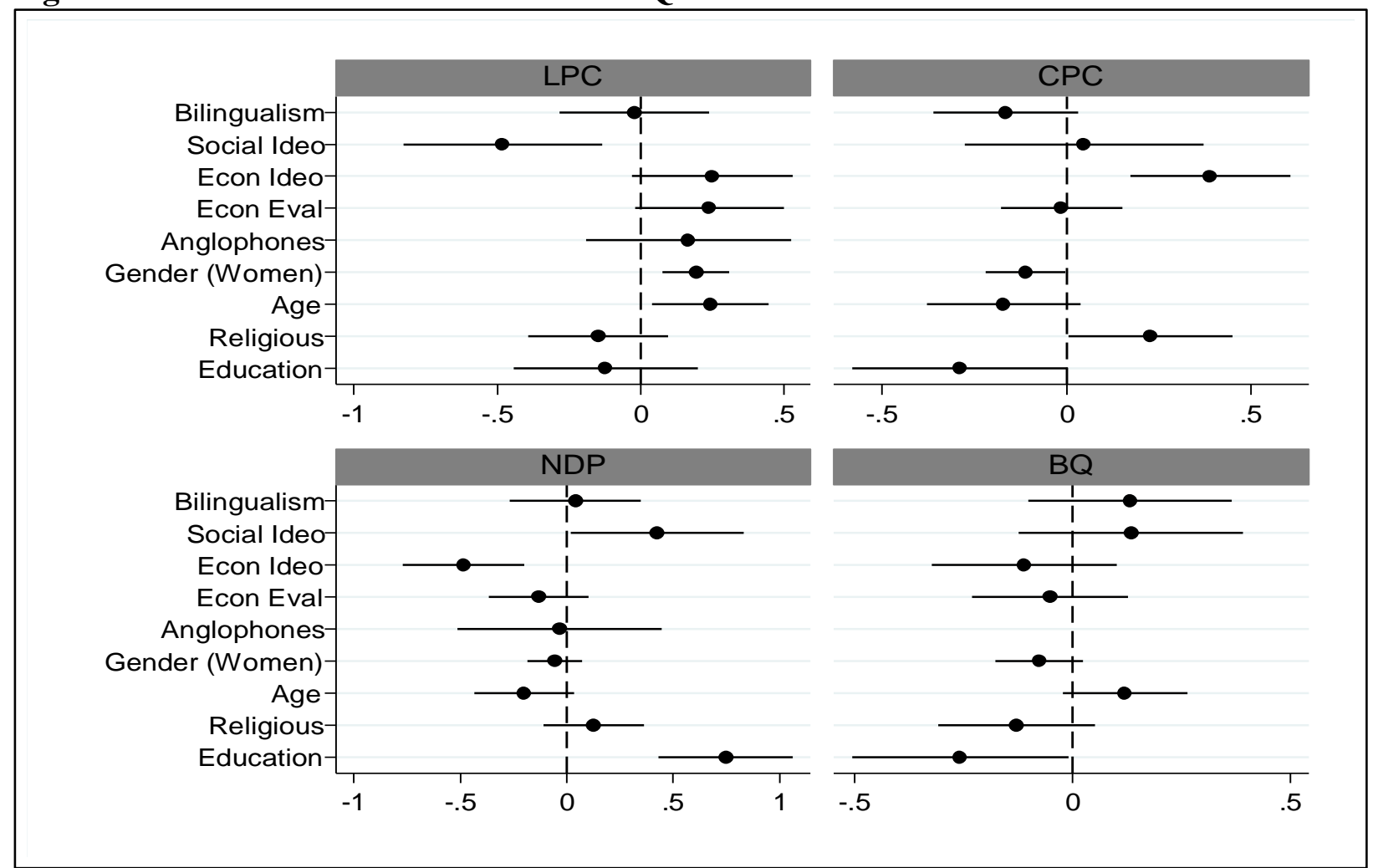

Markers represent average marginal effects (90\%) from logistic regressions. The number of observations for the models are 138 for the LPC and CPC and 129 for the NDP and BQ. There were only four respondents who voted for the GPC in Quebec, thus this party was omitted from these analyses. 
Table 2A: Determinants of Support for Bilingualism

\begin{tabular}{|c|c|c|c|}
\hline \multicolumn{2}{|c|}{ Canada } & \multicolumn{2}{|c|}{ Finland } \\
\hline Mother Tongue: & & Mother tongue: & \\
\hline Anglophones & $\begin{array}{l}-0.15^{*} \\
(0.09)\end{array}$ & Finnophones & $\begin{array}{l}-0.48^{* * * *} \\
(0.07)\end{array}$ \\
\hline $\begin{array}{l}\text { Francophones } \\
\text { (Reference) }\end{array}$ & - & $\begin{array}{l}\text { Swedophones } \\
\text { (Reference) }\end{array}$ & - \\
\hline Allophones & $\begin{array}{l}-0.08 \\
(0.14)\end{array}$ & Allophones & $\begin{array}{l}-0.32 \\
(0.17)\end{array}$ \\
\hline Economic Evaluation & $\begin{array}{l}0.08 \\
(0.07)\end{array}$ & Economic Evaluation & $\begin{array}{l}-0.16 \\
(0.09)\end{array}$ \\
\hline Anglophones $*$ & -0.08 & Finnophones $*$ & $0.23^{* *}$ \\
\hline Economic Evaluation & $(0.09)$ & Economic Evaluation & $(0.09)$ \\
\hline Allophones * & -0.13 & Allophones * & 0.13 \\
\hline Economic Evaluation & $(0.15)$ & Economic Evaluation & $(0.24)$ \\
\hline Religious & $\begin{array}{l}0.04 \\
(0.04)\end{array}$ & Religious & $\begin{array}{l}0.09^{* * *} \\
(0.02)\end{array}$ \\
\hline Gender (Women) & $\begin{array}{l}0.03 \\
(0.02)\end{array}$ & Gender (Women) & $\begin{array}{l}0.03^{\text {*** }} \\
(0.01)\end{array}$ \\
\hline Age & $\begin{array}{l}-0.11^{\text {*** }} \\
(0.04)\end{array}$ & Age & $\begin{array}{l}0.10^{\text {**** }} \\
(0.02)\end{array}$ \\
\hline Education & $\begin{array}{l}0.24^{* * *} \\
(0.05)\end{array}$ & Education & $\begin{array}{l}0.01 \\
(0.03)\end{array}$ \\
\hline Province: & & Regions: & \\
\hline Quebec (Reference): & - & Uusimaa (Reference) & - \\
\hline Newfoundland & $\begin{array}{l}0.02 \\
(0.06)\end{array}$ & Varsinais-Suomi & $\begin{array}{l}0.02 \\
(0.03)\end{array}$ \\
\hline PEI & $\begin{array}{l}-0.09 \\
(0.07)\end{array}$ & Satakunta & $\begin{array}{l}-0.08 \\
(0.05)\end{array}$ \\
\hline Nova Scotia & $\begin{array}{l}-0.03 \\
(0.06)\end{array}$ & Kanta-Häme & $\begin{array}{l}-0.03 \\
(0.04)\end{array}$ \\
\hline New Brunswick & $\begin{array}{l}-0.20^{* * *} \\
(0.07)\end{array}$ & Pirkanmaa & $\begin{array}{l}-0.07^{* * *} \\
(0.02)\end{array}$ \\
\hline Ontario & $\begin{array}{l}-0.05 \\
(0.04)\end{array}$ & Päijät-Häme & $\begin{array}{l}0.02 \\
(0.03)\end{array}$ \\
\hline Manitoba & $\begin{array}{l}-0.02 \\
(0.06)\end{array}$ & Kymenlaakso & $\begin{array}{l}-0.07 \\
(0.04)\end{array}$ \\
\hline Saskatchewan & $\begin{array}{l}-0.03 \\
(0.06)\end{array}$ & Etelä-Karjala & $\begin{array}{l}-0.09^{* * *} \\
(0.02)\end{array}$ \\
\hline Alberta & $\begin{array}{l}-0.15^{* *} \\
(0.06)\end{array}$ & Etelä-Savo & $\begin{array}{l}-0.10^{* * *} \\
(0.03)\end{array}$ \\
\hline British Columbia & $\begin{array}{l}-0.06 \\
(0.05)\end{array}$ & Pohjois-Savo & $\begin{array}{l}-0.15^{* * *} \\
(0.03)\end{array}$ \\
\hline
\end{tabular}




\begin{tabular}{|c|c|c|c|}
\hline & & Pohjois-Karjala & $\begin{array}{l}-0.11^{* * *} \\
(0.03)\end{array}$ \\
\hline & & Keski-Suomi & $\begin{array}{l}-0.06^{* *} \\
(0.02)\end{array}$ \\
\hline & & Etelä-Pohjanmaa & $\begin{array}{l}<-0.00 \\
(0.02)\end{array}$ \\
\hline & & Pohjanmaa & $\begin{array}{l}-0.10^{* *} \\
(0.04)\end{array}$ \\
\hline & & Pohjois-Pohjanmaa & $\begin{array}{l}<0.00 \\
(0.02)\end{array}$ \\
\hline & & Kainuu & $\begin{array}{l}<-0.00 \\
(0.02)\end{array}$ \\
\hline & & Lappi & $\begin{array}{l}-0.02 \\
(0.04)\end{array}$ \\
\hline Constant & $\begin{array}{l}0.55^{\text {*** }} \\
(0.08)\end{array}$ & Constant & $\begin{array}{l}0.83^{\text {*** }} \\
(0.07)\end{array}$ \\
\hline$N$ & 820 & $N$ & 1504 \\
\hline$R^{2}$ & 0.20 & $R^{2}$ & 0.22 \\
\hline
\end{tabular}


Table 3A: Determinants of Vote Choice - Canada (CPC as reference)

\begin{tabular}{|c|c|c|c|c|}
\hline & Liberals & NDP & BQ & Greens \\
\hline \multirow{2}{*}{ Bilingualism } & $1.69^{* * *}$ & $1.94^{* * * *}$ & $2.65^{* *}$ & $1.91^{*}$ \\
\hline & $(0.41)$ & $(0.57)$ & $(1.32)$ & $(1.00)$ \\
\hline \multirow{2}{*}{ Social Ideology } & $-1.59^{* *}$ & 1.42 & 1.16 & -1.03 \\
\hline & $(0.76)$ & $(0.89)$ & $(1.51)$ & $(1.38)$ \\
\hline \multirow{2}{*}{ Economic Ideology } & $-2.76^{* * * *}$ & $-5.29^{* * *}$ & $-4.29^{* * *}$ & $-3.51^{* * *}$ \\
\hline & $(0.55)$ & $(0.86)$ & $(1.32)$ & $(1.21)$ \\
\hline \multirow{2}{*}{ Economic Evaluation } & $<-0.00$ & -0.01 & -0.41 & 1.17 \\
\hline & $(0.45)$ & $(0.55)$ & (1.04) & $(1.47)$ \\
\hline \multicolumn{5}{|l|}{ Mother Tongue: } \\
\hline Francophones (Reference) & - & - & - & - \\
\hline \multirow{2}{*}{ Anglophones } & -0.04 & -0.12 & $-14.33^{* * *}$ & 1.05 \\
\hline & $(0.41)$ & $(0.45)$ & $(0.58)$ & $(0.66)$ \\
\hline \multirow{2}{*}{ Allophones } & 0.42 & 0.05 & 0.45 & $-16.40^{* * *}$ \\
\hline & $(0.51)$ & $(0.73)$ & $(1.54)$ & $(0.71)$ \\
\hline \multirow{2}{*}{ Gender (Women) } & 0.09 & 0.12 & -0.57 & 0.18 \\
\hline & $(0.26)$ & $(0.29)$ & $(0.57)$ & $(0.57)$ \\
\hline \multirow{2}{*}{ Age } & $0.86^{*}$ & 0.14 & $1.47^{*}$ & 0.53 \\
\hline & $(0.45)$ & $(0.50)$ & $(0.84)$ & (1.16) \\
\hline \multirow{2}{*}{ Religious } & -0.64 & -0.06 & -1.52 & -1.41 \\
\hline & $(0.42)$ & $(0.52)$ & $(0.96)$ & $(0.96)$ \\
\hline \multirow{2}{*}{ Education } & 0.80 & 1.21 & -1.35 & -1.37 \\
\hline & $(0.61)$ & $(0.78)$ & $(1.48)$ & $(1.28)$ \\
\hline \multicolumn{5}{|l|}{ Province: } \\
\hline \multirow{3}{*}{ Newfoundland } & - & - & - & - \\
\hline & 0.47 & -0.34 & $-4.06^{* * *}$ & $-17.95^{* * *}$ \\
\hline & $(0.81)$ & $(0.89)$ & $(0.86)$ & $(0.87)$ \\
\hline \multirow{2}{*}{ PEI } & $18.12^{* * *}$ & $15.77^{* * * *}$ & $2.63^{*}$ & $18.16^{* * *}$ \\
\hline & $(0.58)$ & $(0.99)$ & $(1.49)$ & $(1.04)$ \\
\hline \multirow{2}{*}{ Nova Scotia } & 0.63 & $-2.73^{* *}$ & $-4.14^{* * *}$ & $-18.31^{* * * *}$ \\
\hline & $(0.85)$ & $(1.30)$ & $(0.88)$ & $(0.98)$ \\
\hline New Brunswick & 0.76 & -1.28 & $-17.31^{* * * *}$ & 0.16 \\
\hline
\end{tabular}




\begin{tabular}{|c|c|c|c|c|}
\hline & $(1.00)$ & (1.12) & $(1.21)$ & $(1.45)$ \\
\hline \multirow{2}{*}{ Ontario } & -0.63 & $-1.48^{* * *}$ & $-16.93^{* * *}$ & $-1.54^{* *}$ \\
\hline & $(0.45)$ & $(0.53)$ & $(0.82)$ & $(0.78)$ \\
\hline \multirow{2}{*}{ Manitoba } & -0.26 & $-3.13^{* * * *}$ & $-17.60^{* * *}$ & -0.27 \\
\hline & $(0.54)$ & $(0.88)$ & $(0.88)$ & (1.11) \\
\hline \multirow{2}{*}{ Saskatchewan } & -0.20 & -0.42 & $-16.37^{* * * *}$ & -0.78 \\
\hline & $(0.62)$ & $(0.70)$ & $(1.57)$ & $(1.20)$ \\
\hline \multirow{2}{*}{ Alberta } & -1.00 & $-2.16^{* * * *}$ & $-17.21^{* * *}$ & 0.01 \\
\hline & $(0.81)$ & $(0.74)$ & $(1.22)$ & $(1.01)$ \\
\hline \multirow{2}{*}{ British Columbia } & $-1.68^{* * * *}$ & -0.90 & $-16.75^{\text {*** }}$ & -0.84 \\
\hline & $(0.56)$ & $(0.57)$ & $(1.49)$ & $(0.90)$ \\
\hline \multirow{2}{*}{ Constant } & 0.94 & 0.64 & 1.29 & -1.37 \\
\hline & $(0.85)$ & $(1.03)$ & $(1.83)$ & $(3.16)$ \\
\hline$N$ & \multicolumn{4}{|c|}{641} \\
\hline$R^{2}$ & \multicolumn{4}{|c|}{0.22} \\
\hline
\end{tabular}


Table 4A: Determinants of Vote Choice - Finland (KD as reference)

\begin{tabular}{|c|c|c|c|c|c|c|c|}
\hline \multicolumn{8}{|c|}{ Model 1} \\
\hline & KOK & SDP & PS & KESK & VAS & VIHR & RKP \\
\hline \multirow{2}{*}{ Bilingualism } & -1.33 & -0.68 & $-1.88^{*}$ & -0.98 & -1.51 & -1.11 & 1.56 \\
\hline & $(0.89)$ & $(0.81)$ & $(0.82)$ & $(0.77)$ & $(0.94)$ & $(0.90)$ & (1.39) \\
\hline \multirow{2}{*}{ Social Ideology } & -1.06 & -1.65 & 1.23 & -0.77 & $-4.00^{* * *}$ & $-4.37^{* *}$ & $-4.38^{* * *}$ \\
\hline & $(0.96)$ & $(0.88)$ & $(0.87)$ & $(0.83)$ & (1.19) & $(1.09)$ & $(1.43)$ \\
\hline \multirow{2}{*}{ Economic Ideology } & $4.25^{* *}$ & -1.37 & $2.70^{*}$ & 1.27 & -2.01 & -1.27 & 1.20 \\
\hline & (1.34) & $(1.32)$ & $(1.34)$ & $(1.30)$ & $(1.50)$ & (1.39) & $(1.79)$ \\
\hline \multirow{2}{*}{ Economic Evaluation } & $1.74^{* *}$ & 0.83 & 1.04 & $1.82^{* *}$ & 0.51 & 0.67 & 1.48 \\
\hline & $(0.64)$ & $(0.58)$ & $(0.60)$ & $(0.58)$ & $(0.70)$ & $(0.69)$ & $(0.85)$ \\
\hline \multicolumn{8}{|l|}{$\begin{array}{l}\text { Mother Tongue: } \\
\text { Swedophones } \\
\text { (Reference) }\end{array}$} \\
\hline \multirow{2}{*}{ Finnophones } & 0.77 & -0.45 & 0.24 & 0.89 & -0.51 & 0.05 & $-3.65^{* *}$ \\
\hline & $(1.11)$ & $(1.03)$ & $(1.21)$ & $(1.18)$ & $(1.13)$ & $(1.25)$ & $(1.10)$ \\
\hline \multirow{2}{*}{ Allophones } & -0.53 & -2.63 & -1.18 & $-17.52^{* *}$ & -2.64 & -1.34 & $-21.68^{* *}$ \\
\hline & (1.98) & $(1.91)$ & $(1.76)$ & $(1.81)$ & $(1.96)$ & $(2.05)$ & (1.93) \\
\hline \multirow{2}{*}{ Gender (Women) } & 0.12 & 0.25 & 0.08 & 0.06 & 0.46 & 0.41 & 0.48 \\
\hline & $(0.38)$ & $(0.36)$ & $(0.37)$ & $(0.35)$ & $(0.42)$ & $(0.40)$ & $(0.70)$ \\
\hline \multirow{2}{*}{ Age } & 1.10 & 0.96 & $-1.46^{*}$ & 0.53 & -0.19 & -0.70 & 0.51 \\
\hline & $(0.67)$ & (0.68) & $(0.68)$ & $(0.64)$ & $(0.75)$ & $(0.72)$ & $(0.95)$ \\
\hline \multirow{2}{*}{ Religious } & $-6.47^{* *}$ & $-6.80^{* *}$ & $-6.17^{* *}$ & $-5.42^{* *}$ & $-7.71^{* *}$ & $-7.23^{* *}$ & $-6.83^{* *}$ \\
\hline & $(1.54)$ & $(1.54)$ & $(1.56)$ & $(1.54)$ & (1.59) & $(1.56)$ & $(1.72)$ \\
\hline \multirow{2}{*}{ Education } & $2.49^{* *}$ & $-1.89^{* *}$ & $-3.10^{* * *}$ & -0.56 & -1.14 & 1.64 & 2.27 \\
\hline & $(0.78)$ & $(0.69)$ & $(0.77)$ & $(0.68)$ & $(0.88)$ & $(0.84)$ & $(1.73)$ \\
\hline \multirow{2}{*}{\multicolumn{8}{|c|}{$\begin{array}{l}\text { Regions: } \\
\text { Uusimaa (Reference) }\end{array}$}} \\
\hline & & & & & & & \\
\hline \multirow{2}{*}{ Varsinais-Suomi } & 0.39 & 0.25 & 1.35 & 0.18 & 1.20 & 0.06 & 0.03 \\
\hline & $(0.83)$ & $(0.86)$ & $(0.83)$ & $(0.87)$ & $(0.88)$ & $(0.98)$ & $(0.95)$ \\
\hline \multirow{2}{*}{ Satakunta } & 0.10 & 0.82 & 0.89 & 0.86 & 2.01 & $-16.17^{* * *}$ & $-15.71^{* *}$ \\
\hline & $(1.61)$ & $(1.72)$ & $(1.86)$ & $(1.57)$ & $(1.72)$ & $(1.66)$ & (1.74) \\
\hline Kanta-Häme & $13.27^{* *}$ & $15.78^{* *}$ & $16.33^{* *}$ & $15.75^{* *}$ & $15.46^{* *}$ & $14.89^{* *}$ & -0.37 \\
\hline
\end{tabular}




\begin{tabular}{|c|c|c|c|c|c|c|c|}
\hline & $(1.05)$ & $(1.02)$ & $(1.06)$ & $(0.96)$ & $(1.07)$ & $(0.93)$ & $(1.11)$ \\
\hline Pirkanmaa & -0.85 & -0.26 & -0.15 & -0.79 & -0.22 & -0.30 & $-16.28^{* *}$ \\
\hline Päijät-Häme & -0.61 & -0.49 & 0.39 & -0.51 & -1.30 & $-1.94^{*}$ & $-16.59^{* *}$ \\
\hline \multirow{2}{*}{ Kymenlaakso } & -0.79 & 0.59 & 0.42 & -0.31 & -0.47 & -0.96 & $-16.02^{* *}$ \\
\hline & $(0.84)$ & $(0.75)$ & $(0.83)$ & $(0.78)$ & $(0.99)$ & (1.07) & $(0.87)$ \\
\hline Etelä-Karjala & -0.45 & 0.25 & -0.19 & -0.10 & $-16.14^{* *}$ & -0.55 & $-15.77^{* *}$ \\
\hline Etelä-Savo & $(1.14)$ & $(0.76)$ & $(0.77)$ & $(0.77)$ & $(0.76)$ & $(0.85)$ & $(0.94)$ \\
\hline \multirow{2}{*}{ Pohjois-Karjala } & -1.11 & -0.62 & -1.28 & -0.35 & -0.68 & -1.50 & $-16.32^{* *}$ \\
\hline & $(0.78)$ & $(0.73)$ & $(0.84)$ & $(0.68)$ & $(0.87)$ & $(0.91)$ & $(0.84)$ \\
\hline \multirow{2}{*}{ Keski-Suomi } & -1.23 & -0.39 & -0.18 & -0.02 & -1.57 & $-2.34^{*}$ & $-15.75^{* *}$ \\
\hline & $(0.86)$ & $(0.79)$ & $(0.75)$ & $(0.74)$ & $(1.08)$ & $(1.12)$ & $(0.88)$ \\
\hline Etelä-Pohjanmaa & -1.15 & -0.42 & -0.11 & 0.27 & -0.31 & -0.29 & $-17.49^{* *}$ \\
\hline Keski-Pohjanmaa & $(0.98)$ & $(0.85)$ & $(0.84)$ & $(0.72)$ & $(0.82)$ & $(1.10)$ & (1.04) \\
\hline \multirow{2}{*}{ Pohjois-Pohjanmaa } & 0.44 & 0.83 & 2.32 & $2.76^{*}$ & $2.00^{*}$ & 1.42 & $-14.19^{* *}$ \\
\hline & $(1.25)$ & $(1.19)$ & (1.18) & (1.14) & $(1.21)$ & $(1.22)$ & $(1.27)$ \\
\hline \multirow{2}{*}{ Kainuu } & $-24.04^{* *}$ & $-24.78^{* *}$ & -1.21 & -2.13 & $-24.69^{* *}$ & $-24.48^{* *}$ & $-23.59^{* *}$ \\
\hline & $(1.09)$ & $(1.07)$ & $(1.53)$ & $(1.41)$ & $(1.07)$ & $(0.99)$ & $(1.26)$ \\
\hline \multirow{2}{*}{ Lappi } & $15.19^{* *}$ & $16.20^{* *}$ & $15.88^{* *}$ & $16.44^{* *}$ & $14.09^{* *}$ & $15.72^{* *}$ & -0.56 \\
\hline & $(0.74)$ & $(0.73)$ & $(1.01)$ & $(0.59)$ & $(1.29)$ & $(0.70)$ & $(0.71)$ \\
\hline \multirow{2}{*}{ Constant } & 0.51 & $8.22^{* * *}$ & $5.24^{*}$ & 3.38 & $9.72^{* *}$ & $7.28^{* *}$ & 5.05 \\
\hline & $(2.51)$ & $(2.40)$ & $(2.45)$ & $(2.42)$ & $(2.66)$ & $(2.61)$ & $(2.70)$ \\
\hline \multirow{2}{*}{$\begin{array}{l}N \\
R^{2}\end{array}$} & & & & 1098 & & & \\
\hline & & & & 0.25 & & & \\
\hline
\end{tabular}




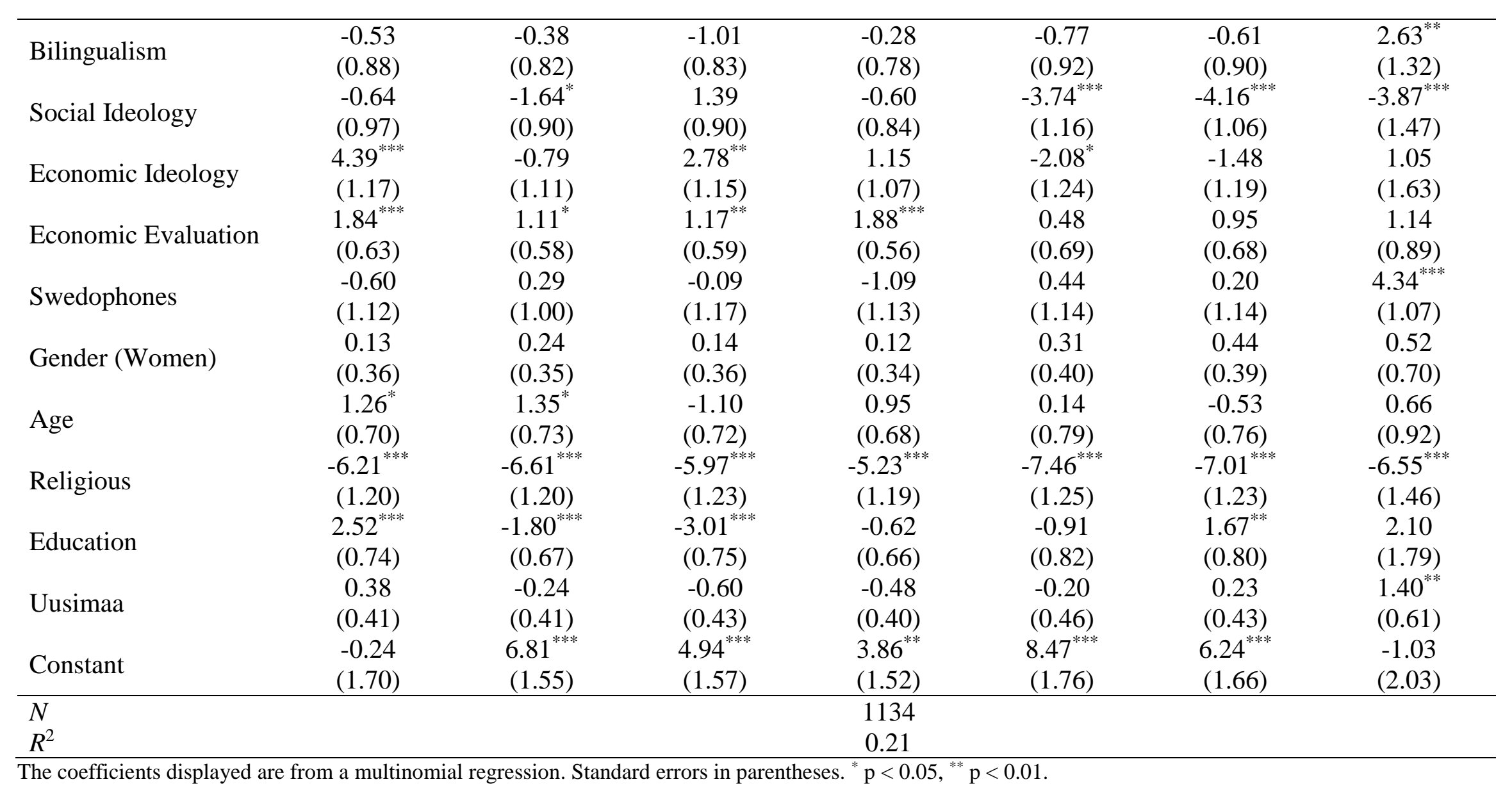

